\title{
Multilevel Analysis: Contextual Effects of School and Psychosocial Determinants on Healthy Sexual Behavior of High School Adolescents in Banyuwangi, East Java, Indonesia
}

\author{
Lia Ulfah Luthfiana'), Pawito²), Eti Poncorini Pamungkasari3) \\ ${ }^{1)}$ Masters Program in Public Health, Universitas Sebelas Maret \\ ${ }^{2)}$ Faculty of Social and Political Sciences, Universitas Sebelas Maret \\ 3)Faculty of Medicine, Universitas Sebelas Maret
}

\begin{abstract}
Background: Along with the development of the era, teenagers began to be faced with various problems and the biggest problems faced by teenagers were sexual problems. Sexual behavior in adolescents who are carried out actively poses a risk of teenage pregnancy and transmission of sexually transmitted diseases. This study aims to analyze the influence related to school context and psychosocial determinants on healthy sexual behavior of adolescents at the age of 15-19 years in Banyuwangi Regency.

Subjects and Method: This study used a cross sectional research design. The study was conducted in 25 high schools/vocational high schools in Banyuwangi Regency, East Java in August to September 2020. Sampling of 225 adolescents was carried out using stratified random sampling and simple random sampling. The dependent variable is healthy sexual behavior. The independent variables include knowledge, self-efficacy, parental support, sources of information/technology, perception of seriousness. Data were collected using a questionnaire. Data were analyzed using multiple logistic regression with Stata 13.

Results: Adolescents will have healthy sexual behavior with high knowledge about healthy sexual behavior $(b=0.23 ; 95 \% C I=0.05$ to $0.41 ; p=0.014)$, have strong self-efficacy $(b=0.14 ; 95 \% \mathrm{CI}=$ 0.01 to $0.27 ; p=0.035)$, had good parental support $(b=0.21 ; 95 \% \mathrm{CI}=0.09$ to $0.34 ; \mathrm{p}=0.001)$, had high exposure to information sources $(b=0.36 ; 95 \% \mathrm{CI}=0.15$ to $0.56 ; \mathrm{p}=0.001)$, and had a high perception of seriousness for weak sexual behavior $(b=0.82 ; 95 \% \mathrm{CI}=0.45$ to $1.19 ; \mathrm{p}<0.001)$. There is an effect of school level on healthy sexual behavior with an ICC of $16.4 \%$.

Conclusion: Healthy sexual behavior in adolescents can increase with high knowledge, strong self-efficacy, having exposure to high sources of information, and having a high perception of seriousness. There is an effect of school level on healthy sexual behavior.
\end{abstract}

Keywords: healthy sexual behavior, school contextual, psychosocial determinants, adolescents

\section{Correspondence:}

Lia Ulfah Luthfiana. Masters Program in Public Health, Universitas Sebelas Maret, Jl. Ir. Sutami 36 A, Surakarta, 57126. Email: luthfianalia7@gmail.com. Mobile: +628523680070o.

\section{Cite this as:}

Luthfiana LU, Pawito, Pamungkasari EP (2021). Multilevel Analysis: Contextual Effects of School and Psychosocial Determinants on Healthy Sexual Behavior of High School Adolescents in Banyuwangi, East Java, Indonesia. J Health Promot Behav. 06(03): 188-20o. https://doi.org/10.26911/thejhpb.2021.06.03.03.

cc) (i) (2) Journal of Health Promotion and Behavior is licensed under a Creative Commons

Attribution-NonCommercial-ShareAlike 4.0 International License.

\section{BACKGROUND}

Along with the development of the era, teenagers began to be faced with various problems and the biggest problems faced by teenagers were sexual problems. Teenagers have an inexhaustible curiosity about the mysteries of sex. Most adolescents, even including those who are trying to develop a mature sexual identity, as far as adults have observed, always experience periods when 
they feel vulnerable and confused in the course of their sexual life (Santrock, 2007). Some reproductive health and sexual problems such as unwanted pregnancies and unsafe abortions (WHO, 2012). Every year in developing countries, it is estimated that 21 million adolescent girls aged 15-19 years and 2 million adolescent girls become pregnant under the age of 15 years (Darroch et al, 2016). Approximately $11 \%$ of adolescent girls aged 15-19 years who gave birth and live in developing and low-income countries (United Nation, 2017).

The physiological development of adolescents and their impact on sexual behavior is much influenced by hormonal and gender factors. In adolescent girls are more influenced by psychosocial factors, including the influence of peer groups (Skinner et al, 2015). In addition, behavioral problems in adolescent girls are a risk factor for early sexual intercourse. So the development of health program interventions related to adolescent sexual health is urgently needed (Pringle et al, 2017).

Sexual behavior carried out by adolescents is motivated by several factors, including increased sexual libido, delays in marriage age, taboos, lack of information about sex, and increasingly free association (Sarwono, 2011). The influence of peers greatly determines adolescents in safe sexual behavior or risky sexual behavior (Peeci, 2016). Peer norms for sexual behavior are more effective in adolescent sexual health programs than in reducing vulnerability to peer pressure to have sex (Van de Bonardt et al, 20-15).

Data from the Banyuwangi Health Service shows that there is still an increase in the number of STI sufferers in Banyuwangi. In 2011 there were 2,902 STI cases, in 2012 it doubled to 4,755 cases, in 2013 there were 4,174 cases and in 2014 there were 4,011 cases, there was a decrease in the number of cases in 2013 and 2014 but this decline was not significant. In terms of age, there were 81 patients aged 15 -19 years in 2014.

Based on a preliminary study by Santoso (2016), high school in Genteng and Banyuwangi sub-districts of 747 students obtained 120 students who had sexual relations. This study aimed to analyze the influence related to the school context and psychosocial determinants on healthy sexual behavior of adolescents at the age of 15-19 years in Banyuwangi Regency.

\section{SUBJECTS AND METHOD}

\section{Study Design}

This was an analytic observational study with a cross sectional design. The study was conducted in Banyuwangi, East Java, from August to September 2020

\section{Population and Sample}

The population in this study were adolescents aged 15-19 years who were in 25 SMA/SMK in Banyuwangi Regency. The number of samples was 225 research subjects consisting of 9 students taken from 25 schools. Sampling was carried out using stratified random sampling and simple random sampling.

\section{Study Variables}

The dependent variable is healthy sexual behavior. Independent variables include knowledge, self-efficacy, parental support, sources of information/technology, perceived seriousness.

4. Operational Definition of Variables Knowledge is knowledge about sexual behavior is knowledge about reproductive health, healthy sexual behavior and the consequences of healthy sexual behavior. engage in risky premarital sex. Continuous data scale, for the purposes of data analysis was changed to a dichotomy with the criteria $0=\operatorname{low}(<2), 1=\operatorname{high}(\geq 2)$. 
Self-efficacy is an individual's belief to take certain health actions, in this case the belief of adolescents to control themselves in order to perform healthy sexual behavior. Continuous data scale, for the purposes of data analysis changed to a dichotomy with the criteria $0=$ weak $(<3), 1=$ strong $(\geq 3)$.

Parental support is an effort made by parents such as reminding how to dress, limiting association with the opposite sex, and providing supervision and attention. Parental supervision is the efforts and attention of parents in controlling the occurrence of healthy sexual behavior. Continuous data scale, for the purposes of data analysis changed to a dichotomy with the criteria $0=\operatorname{not} \operatorname{good}(<2), 1=\operatorname{good}(\geq 2)$.

Sources of information/technology are access to information, namely exposure to various types of information media that can influence healthy sexual behavior. Continuous data scale, for the purposes of data analysis was changed to a dichotomy with the criteria $0=$ low exposure $(<4), 1=$ high exposure $(\geq 4)$.

Perception of seriousness is an individual's perception of the seriousness of a disease and its consequences. Continuous data scale, for the purposes of data analysis was changed to a dichotomy with the criteria $0=\operatorname{low}(<1), 1=\operatorname{high}(\geq 1)$.

School is a strata level based on school accreditation.

\section{Data Analysis}

Univariate analysis to see the frequency distribution and the percentage of the characteristics of the research subjects. Bivariate analysis to determine the relationship between the dependent variable and the independent variable using the chi-square test. Multivariate analysis using logistic regression analysis through a multilevel approach with the Stata13 program to determine the effect of level 2 (school) on healthy sexual behavior.

\section{Research Ethic}

Research ethics include consent form, anonymous, confidentiality, and ethical feasibility. The ethical feasibility in this study came from the Health Research Ethics Committee of Dr M oewardi Hospital Surakarta with number 1271/ XI/ HREC/ 2020.

\section{RESULTS}

\section{Sample Characteristics}

The characteristics of the sample in this study can be seen in table 1 . Table 1 shows the characteristics of the research subjects based on gender, most of which were 155 women (69\%) and 70 men (31\%).

\section{Univariate Analysis}

Descriptive statistical test results of continuous data in the form of variables of knowledge, self-efficacy, parental support, sources of information or technology, perception of seriousness.

Table 1. Characteristics of Research Subjects by Gender

\begin{tabular}{lcc}
\hline \multicolumn{1}{c}{ Sample Characteristics } & N & \% \\
\hline Gender & & \\
Female & 155 & $69 \%$ \\
Male & 70 & $31 \%$ \\
\hline
\end{tabular}


Luthfiana et al./ Contextual Effects of School, Psychosocial Determinants, and Healthy Sexual Behavior

Table 2. Univariate Analysis (Continuous Data)

\begin{tabular}{lccccc}
\hline \multicolumn{1}{c}{ Variable } & n & Mean & SD & Min. & Max. \\
\hline Knowledge & 225 & 3.86 & 0.98 & 2 & 6 \\
Self-efficacy & 225 & 4.90 & 1.32 & 3 & 6 \\
Family Support & 225 & 5.09 & 1.60 & 2 & 7 \\
Source of information/technology & 225 & 5.94 & 1.01 & 4 & 8 \\
Perception of seriousness & 225 & 1.61 & 0.48 & 1 & 2 \\
\hline
\end{tabular}

Table 3. Univariate analysis (dichotomous data)

\begin{tabular}{llcc}
\hline \multicolumn{1}{c}{ Variable } & Criteria & n & \% \\
\hline Knowledge & High & 128 & 56.9 \\
\multirow{2}{*}{ Self-efficacy } & Low & 97 & 43.1 \\
\multirow{2}{*}{ Family support } & Strong & 157 & 69.8 \\
& Weak & 68 & 30.2 \\
\multirow{2}{*}{ Source of information } & Good & 127 & 56.4 \\
\multirow{2}{*}{ Perception of seriousness } & Poor & 98 & 43.6 \\
& High exposure & 144 & 64 \\
& Low exposure & 81 & 36 \\
& High & 138 & 61.3 \\
\hline
\end{tabular}

Table 2 explains that the average knowledge score is 3.86 (mean $=3.86 ; \mathrm{SD}=0.98)$ with the lowest value of 2 and the highest 6 . The self-efficacy variable has an average value of 4.90 (mean $=4.90 ; \mathrm{SD}=1.32$ ) with the lowest value 3 and the highest 6 . The parental support variable has an average value of 5.09 (mean=5.09; $\mathrm{SD}=1.60$ ) with the lowest value 2 and the highest 7. The variable source of information/technology has an average value of 5.94 (mean $=5.94$; $\mathrm{SD}=1.01$ ) with the lowest score 4 and the highest 8. Perception of seriousness had an average score of 1.61 (mean $=1.61 ; \mathrm{SD}=0.48)$ with the lowest score 1 and the highest 2.

The characteristics of the 225 adolescents who were the research subjects are shown in Table 3 with the following explanation: most of the adolescents have high knowledge with a total of 28 (56.9\%) while adolescents with low knowledge are 97 (43.1\%). Adolescents with strong self-effi- cacy were 157 (69.8\%) while adolescents with weak self-efficacy were 68 (30.2\%). Adolescents who have strong parental support are 127 (56.4\%) while adolescents who have weak parental support are 98 (43.6\%). Adolescents with strong self-efficacy were 157 (69.8\%) while adolescents with weak self-efficacy were 68 (30.2\%). Adolescents who have exposure to information sources/ high technology are 144 (64\%) while adolescents who have exposure to sources of information / technology are low by $81(36 \%)$. Adolescents with a high perception of seriousness were 138 (61.3\%), while adolescents with a low perception of seriousness were 87 (38.7\%).

\section{Bivariate Analysis}

Bivariate analysis was performed using the chi-square test. Bivariate analysis based on the results of this study can be seen in Table 4. 
Luthfiana et al./ Contextual Effects of School, Psychosocial Determinants, and Healthy Sexual Behavior

Table 4. Bivariate Analysis of the Determinants of Healthy Sexual Behavior

\begin{tabular}{|c|c|c|c|c|c|c|c|c|}
\hline \multirow{3}{*}{ Independent variable } & \multicolumn{4}{|c|}{$\begin{array}{c}\text { Healthy Sexual } \\
\text { Behavior }\end{array}$} & \multirow{2}{*}{\multicolumn{2}{|c|}{ Total }} & \multirow{3}{*}{$\mathbf{O R}$} & \multirow{3}{*}{$\mathbf{p}$} \\
\hline & \multicolumn{2}{|c|}{ No } & \multicolumn{2}{|c|}{ Yes } & & & & \\
\hline & $\mathbf{N}$ & $\%$ & $\mathbf{N}$ & $\%$ & $\mathbf{N}$ & $\%$ & & \\
\hline \multicolumn{9}{|l|}{ Knowledge } \\
\hline High & 22 & 17.19 & 106 & 82.81 & 128 & 100 & \multirow[t]{2}{*}{7.81} & \multirow[t]{2}{*}{$<0.001$} \\
\hline Low & 60 & 61.86 & 37 & 38.14 & 97 & 100 & & \\
\hline \multicolumn{9}{|l|}{ Self-efficacy } \\
\hline Strong & 42 & 26.75 & 115 & 73.25 & 157 & 100 & \multirow[t]{2}{*}{3.91} & \multirow[t]{2}{*}{$<0.001$} \\
\hline Weak & 40 & 58.82 & 28 & 41.18 & 68 & 100 & & \\
\hline \multicolumn{9}{|l|}{ Family Support } \\
\hline Good & 21 & 16.54 & 106 & 83.46 & 127 & 100 & \multirow[t]{3}{*}{8.32} & \multirow[t]{2}{*}{$<0.001$} \\
\hline Lacking & 61 & 62.24 & 37 & 37.76 & 98 & 100 & & \\
\hline \multicolumn{8}{|l|}{ Source of information } & \\
\hline High Exposure & 25 & $17 \cdot 36$ & 119 & 82.64 & 144 & 100 & \multirow[t]{2}{*}{11.30} & \multirow[t]{2}{*}{$<0.001$} \\
\hline Low exposure & 57 & 70.37 & 24 & 29.63 & 81 & 100 & & \\
\hline \multicolumn{9}{|l|}{ Perception of seriousness } \\
\hline High & 30 & 21.74 & 108 & 78.26 & 138 & 100 & \multirow[t]{2}{*}{$5 \cdot 34$} & \multirow[t]{2}{*}{$<0.001$} \\
\hline Low & 52 & 59.77 & 35 & 40.23 & 87 & 100 & & \\
\hline
\end{tabular}

Table 4 shows the results of the chi-square test of the effect of healthy sexual behavior with knowledge, self-efficacy, parental support, sources of information or technology and perceived seriousness, namely:

a. Adolescents with high knowledge (82.81\%) tended to have a percentage of healthy sexual behavior than those with low knowledge (38.14\%), and the difference was statistically significant $(\mathrm{p}<0.001)$.

b. Adolescents with strong self-efficacy (73.25\%) tended to have a higher percentage of healthy sexual behavior than those with weak self-efficacy (41.18\%) and the difference was statistically significant $(\mathrm{p}<0.001)$.

c. Adolescents with good parental support (83.46\%) tended to have a higher percentage of healthy sexual behavior than adolescents with poor parental support (37.76\%) and the difference was statistically significant $(\mathrm{p}<0.001)$. d. Adolescents with high exposure to information sources (82.64\%) tended to have a higher percentage of healthy sexual behavior than low exposure (29.63\%) and the difference was statistically significant $(\mathrm{p}<0.001)$.

e. Adolescents with a high perception of seriousness (78.26\%) tended to have a higher percentage of healthy sexual behavior than those with a low perception of seriousness (40.23\%) and the difference was statistically significant $(\mathrm{p}<0.001)$.

\section{Multivariate Analysis}

Multilevel analysis explained the effect of more than one independent variable (intentions, attitudes, subjective norms, peer support, family intimacy and self-efficacy) with the dependent variable (premarital sex behavior). The results of the multivariate analysis using multiple logistic regression with a multilevel approach can be seen in Table 5 . 
Luthfiana et al./ Contextual Effects of School, Psychosocial Determinants, and Healthy Sexual Behavior

Table 5. Multilevel Logistic Regression Analysis of Premarital Sex Behavior

\begin{tabular}{|c|c|c|c|c|}
\hline \multirow{2}{*}{ Independent Variables } & \multirow{2}{*}{ b } & \multicolumn{2}{|c|}{$95 \% \mathrm{CI}$} & \multirow[b]{2}{*}{$\mathbf{p}$} \\
\hline & & Lower Limit & Upper Limit & \\
\hline \multicolumn{5}{|l|}{ Fixed effect } \\
\hline Knowledge (High) & 0.23 & 0.05 & 0.41 & 0.014 \\
\hline Self-efficacy (strong) & 0.14 & 0.01 & 0.27 & 0.035 \\
\hline Parental support (good) & 0.21 & 0.09 & 0.34 & 0.001 \\
\hline \multicolumn{4}{|l|}{ Perception of seriousness (high) } & 0.001 \\
\hline \multicolumn{5}{|l|}{ Random effect } \\
\hline School & 0.82 & 0.45 & 1.19 & $<0.001$ \\
\hline Var (constant) & 0.24 & 0.09 & 0.12 & \\
\hline \multicolumn{5}{|l|}{$\mathrm{N}$ observation $=225$} \\
\hline \multicolumn{5}{|l|}{$\mathrm{N}$ group $=25$} \\
\hline \multicolumn{5}{|l|}{ Average group $=9, \min =9, \max =9$} \\
\hline \multicolumn{5}{|l|}{ Log likelihood= -359.75 } \\
\hline $\mathrm{p}<0.001$ & & & & \\
\hline $\mathrm{ICC}=16.41 \%$ & & & & \\
\hline
\end{tabular}

Table 5 results of multilevel multiple logistic regression can be explained as follows:

a. The influence of knowledge on healthy sexual behavior in adolescents

The results of multilevel logistic regression analysis showed that there was a positive relationship between knowledge and healthy sexual behavior in adolescents. Adolescents with high knowledge of healthy sexual behavior had a 0.23 unit higher probability (logodd) for healthy sexual behavior than adolescents with low knowledge $(b=0.23$; 95\% $\mathrm{CI}=0.05$ to $0.41 ; \mathrm{p}=0.014$ ).

b. Effect of self-efficacy on healthy sexual behavior in adolescents

There is a positive relationship between self-efficacy and healthy sexual behavior in adolescents. Adolescents with strong selfefficacy have a probability (logodd) to perform healthy sexual behavior by 0.14 units higher than adolescents with weak self-efficacy $(b=0.14 ; 95 \% \mathrm{CI}=0.01$ to $0.27 ; \mathrm{p}=$ o.035). c. The effect of parental support on healthy sexual behavior in adolescents

There is a positive relationship between parental support and healthy sexual behavior in adolescents. Adolescents with good parental support had a 0.21 unit higher probability (logodd) of healthy sexual behavior than adolescents with poor parental support $(\mathrm{b}=0.21 ; 95 \% \mathrm{CI}=0.09$ to $0.34 ; \mathrm{p}=$ o.001).

d. The effect of exposure to information sources on healthy sexual behavior in adolescents

There is a positive relationship between sources of information technology and healthy sexual behavior in adolescents. Adolescents with high exposure to information sources had a probability (logodd) to perform healthy sexual behavior by 0.36 units higher than adolescents with low exposure to information sources $(b=0.36 ; 95 \% \mathrm{CI}=$ 0.15 to $0.56 ; \mathrm{p}=0.001$ ).

e. The effect of perceived seriousness on healthy sexual behavior in adolescents

There is a positive relationship between perceived seriousness and healthy sexual 
behavior in adolescents. Adolescents with a high perception of seriousness had a 0.82 unit lower probability (logodd) of engaging in premarital sexual behavior than adolescents with low family intimacy $(b=0.82$; $95 \% \mathrm{CI}=0.45$ to $1.19 ; \mathrm{p}=<0.001)$.

\section{f. School contextual influence on healthy sexual behavior}

The results of the ICC $16.4 \%$, indicate that in each school strata have a contextual influence on variations in premarital sex behavior of $24.6 \%$. This figure is greater than the role of thumb of $8-10 \%$, so the contextual influence of the school shown from the multilevel analysis is very important to note.

\section{DISCUSSION}

1. The influence of knowledge on healthy sexual behavior in adolescents

The results of this study indicate that knowledge has an influence on healthy sexual behavior in adolescents. Based on table 5 , it can be interpreted that there is a positive and statistically significant relationship. Adolescents with strong knowledge to have healthy sexual behavior have a 0.23 unit lower probability (logodd) of premarital sex than adolescents with low intentions $(b=$ $0.23 ; 95 \% \mathrm{CI}=0.05$ to $0.41 ; \mathrm{p}=0.014$ )

Knowledge of sexual behavior including reproductive health, the consequences of risky sexual behavior, and the types of sexual activity usually carried out. The results of this study indicate that low knowledge increases risky sexual behavior (Brüll et al., 2016).

Illness and unplanned pregnancy are associated with moderate to low levels of knowledge about sexual health (Morales et al., 2018). A study conducted by Albertos et al., (2016), a questionnaire answered by 6208 adolescents showed that the greater the knowledge, the lower the frequency of risk behavior among adolescents, and vice versa, if the knowledge is low then the quency of risk behavior is high.

According to Wardhani (2017) there is a direct and positive relationship between sexual knowledge and adolescent sexual behavior. The results of the analysis also show that there is a direct and negative relationship between sexual knowledge through exposure to pornography in electronics, and there is a direct positive relationship between peer group sexual knowledge on adolescent sexual behavior. The higher the knowledge about sexuality, the better the sexual behavior.

Bakti (2017) states that adolescents who have good knowledge of sexual function and reproductive health tend to avoid deviant sexual behavior or unhealthy sexual behavior in adolescents.

\section{The effect of self-efficacy on heal-} thy sexual behavior in adolescents

The results of this study indicate that there is a positive relationship between attitudes and healthy sexual behavior in adolescents. Adolescents with strong self-efficacy had a probability (logodd) of engaging in premarital sexual behavior 0.14 units higher than adolescents with weak self-efficacy $(b=$ 0.14; 95\% CI=0.01 to 0.27; $\mathrm{p}=0.035$ ).

This statement is supported by previous research from Morris, Young and Jones (2010), that self-esteem is higher when not having sex before marriage. The results supported by Hidayat (2013), which shows the effect of price on dating sexual behavior of adolescents.

Self-efficacy is a person's confidence in his ability to do or not do a behavior. Self-efficacy is developed through personal experience, social learning and social persuasion. Ghaffari et al., (2016) stated that students who have high self-efficacy are able to control themselves against sexual 
stimulation and can avoid premarital sex behavior.

Self-efficacy is a self-referential assessment of how well a person can exercise control over their own behavior. Self-efficacy in particular can reduce premarital sexual behavior. Research by Boone et al., (2015) states that someone who has higher self-efficacy is also more knowledgeable about sexual health and behavior, thereby reducing the likelihood of premarital sexual behavior. One's religion and religiosity have a strong positive influence in increasing self-efficacy. Someone who has a belief in sexual abstinence and prohibits the use of contraception will avoid premarital sex (Ajayi and Olamijuwon, 2019).

\section{The influence of parental support} on healthy sexual behavior in adolescents

There is a relationship between parental support and healthy sexual behavior in adolescents. Adolescents with good parental support had a 0.21 unit higher probability (logodd) of healthy sexual behavior than adolescents with poor parental support $(b=0.21 ; 95 \% \mathrm{CI}=0.09$ to $0.34 ; \mathrm{p}=$ o.001).

Winarni et al. Association between Self-Esteem chards (2013) that adolescents who grow up in families or parents who care for and communicate about sex with them will make adolescents engage in safer sexual behavior. Parents have the ability to influence their children's sexual decisions. Parent-child communication about sex and parent-child relationships are important factors in shaping safe sex attitudes and practices.

This is supported by Suwarni (2009), the results of the study show that there is a relationship between parental monitoring and adolescent sexual behavior. Ahmadi et al (2013) stated that parental supervision and affiliation with peers are associated with deviant adolescent sexual behavior.

Communication between parents and children plays an important role in fostering their relationship. Parents who are least able to communicate with him will cause conflicting relationships so that it can have an impact on adolescent sexual behavior. Parental supervision can be defined as parental knowledge of their children's activities and what they do. This is tantamount to a form of protection against parental risk from adolescent behavior, such as the use of harmful substances or sexual behavior, where the supervision varies according to age, sex or ethnicity and generally declines with age (Tome, 2002). Hidayah and Maryatun (2013) stated that lack of parental supervision will accelerate adolescent sexual relations. Parental supervision is an important factor influencing adolescent sexual behavior. Adolescents who watch their parents will delay or even avoid sexual intercourse while adolescents without parental supervision will have sexual relations at an earlier age.

\section{The effect of exposure to informa- tion sources on healthy sexual be- havior in adolescents}

There is a positive relationship between sources of information technology and healthy sexual behavior in adolescents. Adolescents with high exposure to information sources had a probability (logodd) to perform healthy sexual behavior by 0.36 units higher than adolescents with low exposure to information sources $(b=0.36$; 95\% $\mathrm{CI}=0.15$ to $0.56 ; \mathrm{p}=0.001)$.

According to Lubis (2017), high exposure to pornography has a greater chance of having risky sexual behavior than adolescents with low exposure to pornography. Print media and electronic media are the most widely used media for the spread of pornography. Hormonal development in 
adolescents and provoke a desire to try in sexual activity.

There is a direct and negative relationship between exposure to electronic pornography and adolescent sexual behavior which is statistically significant. Teenagers' interest in pornographic material on the internet is related to the transition period experienced by teenagers. Adolescents experience various kinds of changes, namely physical, sexual, emotional, religious, moral, social, and intellectual aspects (Hurlock, 2011).

The spread of information media and sexual stimulation through mass media, especially electronic media, namely the presence of advanced technology such as the internet, digital magazines, television, and video, makes teenagers tend to want to know, try, and imitate what they see and hear. Print and electronic media are the most widely used media to disseminate pornography. Hormonal development in adolescents is driven by exposure to electronic media which brings curiosity and provokes the desire to experiment in sexual activity.

Changes in the sexual aspect are related to the maturation of the pituitary gland which stimulates the release of hormones that affect the reproductive organs that increase the child's sexual arousal. Teenagers become more aware of many things related to sex and try to find more information about sex, including information about sex which is very easy to get from the Internet. Teenagers are one of the segments that are vulnerable to the presence of pornography, especially pornographic sites. Furthermore, Hurlock also mentions that teenagers are more interested in sex material in the form of pornography compared to sex material in the form of education (Hurlock, 2011).

\section{The effect of perceived seriousness on healthy sexual behavior in adolescents}

There is a positive relationship between perceived seriousness and healthy sexual behavior in adolescents. Adolescents with a high perception of seriousness had a 0.82 unit higher probability (logodd) of engaging in healthy sexual behavior than adolescents with a low perception of seriousness $(b=$ $0.82 ; 95 \% \mathrm{CI}=0.45$ to $1.19 ; \mathrm{p}=<0.001)$.

Perceptions of seriousness or severity of illness include a person's beliefs about the disease itself (for example, whether the disease is life-threatening, causes disability, or pain) as well as the wider impact that the disease has on a person's ability to describe his or her social functioning (effect on work, family life, and social life). effect on the emergence of social stigma and social relations, and so on) (Murti, 2018).

Teenagers perceptions of sexual behavior will be formed through exposure to the knowledge they get from school, social media, parents and other sources. Perception will form a teenager's opinion about something that is believed and then with the support of intention or intention it will be realized in real action. If the adolescent's perception of positive sexual behavior means that it will affect the adolescent's intention not to engage in risky sexual behavior (Tenkoranga, Maticka Tyndaleb, \& Rajultona, 2011).

\section{School contextual influence on premarital sex behavior in adole- scents}

The school level shows that there is a contextual effect on variations in healthy sexual behavior $(\mathrm{ICC}=16.41 \%)$. The variation of healthy sexual behavior as much as $16.41 \%$ is influenced by the score table 4.5 shows that the ICC value in this study is greater 
School is a place to promote reproductive health so that it can prevent sexual behavior and early sexual intercourse. Studying at school reduces the amount of free time that teenagers have and improves education to prepare for the career needs of teenagers and empowers teenagers with the necessary skills so that they can reduce premarital sexual behavior. This implies that increasing school participation can be an effective strategy to promote accurate information to students about reproductive health issues such as awareness of fertility, sexual intercourse, pregnancy and STIs (Alhassan and Dodoo, 2020)

Better education is a protective factor for risky sexual behavior as well as premarital sex, suggesting that the school environment may provide a context in which early sexual activity is discouraged (Yip et al., 2013)

A systematic review and meta analysis study conducted by Sani et al., (2016) stated that interventions to protect adolescents from sexual behavior and STIs have the potential to be inclusive and to provide comprehensive preventive education and training. School-based sexual health education may be an effective strategy for promoting reproductive health. There are still many schools that have not provided education related to reproductive health, this is shown by the fact that there are still many teenagers who have less knowledge about reproductive health and the impact of healthy sexual behavior.

\section{AUTHOR CONTRIBUTION}

Lia Ulfah Luthfiana as the main researcher plays a role in coordinating research, conducting all stages of research, and completing research manuscripts. Pawito plays a role in developing ideas, research designs, and research hypotheses. Eti Poncorini Pamungkas played a role in preparing the research framework, processing research data, representing the results of research analysis, and preparing research manuscripts

\section{FUNDING AND SPONSORSHIP}

This study is self-funded.

\section{CONFLICT OF INTEREST}

There is no conflict of interest in this study.

\section{ACKNOWLEDGMENT}

We would like to thank all the Principals of Banyuwangi Regency for allowing this research to be carried out. Thank you to the students who participated and were willing to be respondents in the research.

\section{REFERENCES}

Admodiwiro S (2000). Manajemen Penidikan (Education Management). Jakarta: PT.Ardadizya

Ajayi AI, Olamijuwon EO (2019). What predicts self-efficacy? Understanding the role of sociodemographic, behavioural and parental factors on condom use self-efficacy among university students in Nigeria. a. PLoS ONE 14(8): e0221804. https://doi.org/10.1371/journal.pone.0221804.

Ayodhyaputri W (2015). Kasus KTD Surabaya Terbesar se-Jawa Timur. http://www.samsaranews.com/kasusktd surabaya-terbesar-se-jawa-timur/ Accessed October 2019.

Bakti M (2017). Hubungan Pengetahuan kesehatan reproduksi remaja dan keintiman keluarga dengan sikap seksual pranikah di SMAN 1 Sukoharjo. Digital Library. Retrieved from https://digilib.uns.ac.id/dokumen/detail/2 5752/HubunganPengetahuanKesehat anReproduksiRemajadanKeintimanK eluargaDenganSikapSeksualPranikahdi-SMAN-1-Sukoharjo 
Boone MR, Cherenack EM, Wilson PA (2015). Self-efficacy for sexual risk reduction and partner HIV Status as correlates of sexual risk behavior among HIV-positive adolescent girls and women. AIDS Patient Care STDS, 29(6): 346-353. https://doi.org/10.1089/apc.2014.0175.

Darroch J, Woog V, Bankole A, AshfordLS. (2016). Adding it up: Cost and benefits of meeting the contraceptive needs of adolescent. New York: Guttmacher Institute. https://www.unfpa.org/publictions/adding-it-2012. accessed October 2019.

Direktorat Jenderal Pendidikan Dasar dan Menengah (2018). Data Pokok Pendidikan dasar Menengah (Basic Data for Secondary Education). Jakarta: Kementrian Pendidikan dan Kebudayaan.

Erawati F (2017). Determinan Psikososial Perilaku Seksual Berisiko Pada Siswa Sekolah Menengah Atas di Kabupaten Merauke (Psychosocial Determinants of Risky Sexual Behavior in High School Students in Merauke Regency). http://journal.fkm.ui.ac.id/-kesmas/article/view/1163. Accessed October 2019

Envuluade EA, Van de Kwak A, Zwanikken $\mathrm{P}$, Zoakah Al (2017). Exploring the factors influencing adolescent behaviour in Plateau State Nigeria. American Journal of Medicine and medical Sciences 2017, 7 (1): 1-6 DOI: 10.5923/j.ajjmms. 20170701.01.

Fearon E, Wiggins RD, Pettifor AE, Hargreaves JR (2015). Is te sexual behaviour of young people in sub-saharan africa influenced by their peers? A systematic review. https://www.researchgate.net/publication/283323 330_Is_the_sexual_behaviour_of_yo ung_people_insubSahara_Africa_infl
uenced_by_their_peers_A_systemati c_review. Accessed October 2019.

Ghaffari M, Gharghani ZG, Mehrabi Y, Ramezankhani A, Movahed M (2016). Premarital sexual intercourse-related individual factors among Iranian adolescents: A qualitative study. Iran Red Crescent Med J, 18(2): 21220. https://doi.org/10.5812/ircmj.21220.

Hurlock B, Elisabeth E (1978). Perkembangan Anak Jilid 2 (Child Development Volume 2). Jakarta: Erlangga.

Hurlock EB (1999). Psikologi Perkembangan: Suatu Pendekatan Sepanjang Rentang Kehidupan (Developmental Psychology: An Approach Throughout the Lifespan). Edisi Kelima.Jakarta: Erlangga.

Hurlock EB (2011). Psikologi Perkembangan (Developmental psychology). Jakarta: Erlangga.

Kementrian Kesehatan (2013). Statistik Kasus HIV/AIDS di Indonesia Juni 2013 (Statistics of HIV/AIDS Cases in Indonesia June 2013). Jakarta: Ditjen PP dan PL.

Kusumaryani M (2017). Ringkasan Studi: Prioritaskan kesehatan Reproduksi Remaja Untuk Menmati Bonus Demografi (Study Summary: Prioritize Adolescent Reproductive Health To Enjoy Demographic Bonus). Jakarta : Lembaga Demografi Fakultas Eonomi Dan Bisnis Universitas Indonesia. http://ldfebui.org/wpcotenet/uploud /2017/o8/BN-06-2017.pdf. Diakses 2 Oktober 2019.

Lubis (2017). Peran teman sebaya dan paparan media pornografi terhadap perilaku seksual remaja di Sekolah Tinggi Ilmu Kesehatan Yogyakarta (The role of peers and pornographic media exposure to adolescent sexual behavior at the School of Health Sciences Yogyakarta). https://stikes- 
Luthfiana et al./ Contextual Effects of School, Psychosocial Determinants, and Healthy Sexual Behavior

yogyakarta.ejournal.id/JKSI/article/v iew/65.

Mawardah M (2012). Hubungan antara kelompok teman sebaya dan regulasi emosi dengan kecendrungan menjadi pelaku cyberbullying pada remaja (Relationship between peer groups and emotion regulation with tendency to be cyberbullying adolescents). Thesis. Yogyakarta: Pascasarjana UGM.

Murti B (2018). Teori Promosi dan Perilaku Kesehatan (Health Promotion and Behavior Theory). Jawa Tengah: Bintang Fajar Offset.

Morales A, Vallejo-Medina P, Abello-Luque D, Saavedra-Roa A, García-Roncallo P, Gomez-Lugo M, García-Montaño E, et al. (2018). Sexual risk among Colombian adolescents: Knowledge, attitudes, normative beliefs, perceived control, intention, and sexual behavior. BMC Public Health, 18(1): 1377. https://doi.org/10.1186/s128890186311-y.

Peci, Cand B (2016). The effect of parental maediaton andpeer group on adolecnt sexual intiation. International Journal Of Education Annd Research. 4(12). http://www.ijen.com/journal/2016/d esember-2016/22.pdf.

Population Reference Buerau (2017). World populastion data: Focus On Youth. America: American Community Survey. https//worldpopdata.org/table. Accessed October 10, 2019

Pringle J, Mills KL, McAteer J, Jepson R, Hogg E, Anand N, Blakemore SJ (2017). The physiology of adolescent sexual behaviour: A systematic review. Cogent Soc Sci. 3(1):1368858. https://doi.org/10.1080/23311886.20 17.1368858 .

Santrock, John W (2011). Perkembangan Anak Edisi 7 Jilid 2 (Child Develop- ment Edition 7 Volume 2). Jakarta: Erlangga.

Santrock, JW. (2007). Perkembangan Anak (Child development). Jilid 1 Edisi Kesebelas. Jakarta: PT Erlangga.

Survey Demografi dan Kesehatan Indonesia (2017). Kesehatan Reproduksi (Reproduction health). Jakarta: Badan Kependudukan dan Keluarga Berencana Nasional (BKKBN) dan badan Pusat Statistik (BPS). https://ekoren.bkkbn.go.id/wpcontent/upload s/2018/10/Laporan-SDKI 2017Remaja.pdf. Diakses 2 November 2019.

Susanto BNA, Nurhaeni IDA (2018). Do schools affect unsafe sexual behaviors among high school students in Boyolali, Central Java? A Multilevel Analysis Approach. J Health Promot Behav. 4(2): 230-239. https://doi.org/10.26911/thejhpb.2018.03.04.02.

Tenkoranga EY, Maticka-Tyndaleb E, Rajultona F (2011). A multi-level analysis of risk perception, poverty and sexual risk-taking among young people in Cape Town, South Africa. Health Place. 17(2):525-35. https://doi.org/10.1016/j.healthplace.2010.12 .009.

Tome G. de Matos MG, Simoes C, Camacho, I, AlvesDiniz J (2012). How Can Peer Group Influence the Behaviour of Adolescent Explanatory Model. http://doi.org/10.5539/gjhs.v4n2p26

Setiowati TA, Pamungkasari EP, Prasetya H (2019). Application of theory of planned behavior on sexual behavior in female adolescents. J Health Promot Behav. 4(2): 126-136. https://doi.org/10.26911/thejhpb.2019.04.02.05 .

Triyanto E, Setiyani R, Wulansari R (2014). Pengaruh dukungan kleuarga dalam meningkatkan perilaku adaptif remaja pubertas (The effect of family support 
in improving adaptive behavior of puberty adolescents). Jurnal Keperawatan Padjadjaran. 2(1). https://doi.org/10.24198/jkp.v2i1.76.

UNFPA (2017). Adolescent Pregnancy: Overview. https://www.unfpa.org/adolescent-pregnancy. Accessed October 17, 2019

van de Bongardt D, Reitz E, Sandfort T, Deković M (2015). A meta-analysis of the relations between three types of peer norms and adolescent sexual behavior. Pers Soc Psychol Rev. 19(3): 203-34. https://doi.org/10.1177/1088868314544223.

Wardhani Y, Demartoto A (2017). Effect of sexual knowledge and attitude, exposure to electronic media pornography, peer group, and family intimacy, on sexual behaviors among adolescents in Surakarta. J Health Promot Behav, 2(2): 138-147. https://doi.org/10.26911/-thejhpb.2017.02.02.04.

WHO.(2012). Adolescent Health. https://www.who.int/topics/adolescent_healt h/en/ Diakses tanggal 3Oktober 2019

Widman L, Choukas-Bradley S, Helms SW, Prinstein MJ (2016). Adolescent suscebtibility to peer influence in sexual situation. J Adolesc Health. 58(3): 323-9. http://doi.org/10.101/j.jadohealth.2015.10.253.

Winarni (2016). Asosiasi antara harga diri, efikasi diri, temn, kontrol orang tua, dan perilaku seksual pada remaja di Sekolah Menengah Surakarta. J Health Promot Behav. 1(1): 46-53. https://doi.org/10.26911/thejhpb.2016.01.01.07. 